\title{
Diagnostic difficulties in a patient with paroxysmal cold haemoglobinuria and acute kidney injury
}

\author{
MARIA DANIEL ${ }^{l}$, ANNA ADAMOWICZ-SALACH' ${ }^{2}$ HANNA SZYMANIK-GRZELAK ${ }^{1}$
}

${ }^{1}$ Department of Paediatrics and Nephrology, Medical University of Warsaw, Poland

${ }^{2}$ Department of Paediatrics, Haematology, and Oncology, Medical University of Warsaw, Poland

\begin{abstract}
Paroxysmal cold haemoglobinuria (PCH) is a form of autoimmune haemolytic anaemia (AIHA) characterised by a sudden onset of haemoglobinuria, either spontaneously or following exposure to cold. In children, it is commonly seen following a viral illness or after immunisation. Diagnosis of PCH is confirmed by a positive Donath Landsteiner $(D L)$ test in which biphasic haemolysins are detected. However, in a real clinical setting, the serological diagnosis of PCH is not always easy. PCH can cause tubular renal injury, which in turn can lead to renal impairment. We describe a case of a two-year-old boy who was admitted to the hospital with pallor, jaundice, dehydration, and dark urine. Two weeks before admission, the child had an upper respiratory tract infection. Laboratory tests showed severe anaemia (haemoglobin 4.5g/dl, haematocrit 11.5\%, LDH 8525 U/l), hyperbilirubinaemia (104 بmol/l), haemoglobinuria, and acute kidney injury: GFR $43.9 \mathrm{ml} / \mathrm{min} / 1.73 \mathrm{~m}^{2}$ (grade 2 according to Acute Kidney Injury Network). The direct antiglobulin test was positive for C3c and C3d complement components. The diagnosis of PCH was confirmed by the presence of biphasic antibodies in a DL test on the third day of hospitalisation. The patient received supportive treatment.
\end{abstract}

Key words: paroxysmal cold haemoglobinuria, autoimmune haemolytic anaemia, DonathLandsteiner test, acute kidney injury.

(Centr Eur J Immunol 2017; 42 (4): 404-406)

\section{Introduction}

Paroxysmal cold haemoglobinuria $(\mathrm{PCH})$ is mediated by biphasic haemolysins, which sensitise red blood cells in a cold environment and cause direct intravascular haemolysis when the red blood cells reach the temperature of $37^{\circ} \mathrm{C}[1,2]$. Acute attacks of anaemia are often severe, but in most cases only supportive care is required [1-5]. Kidney injury due to $\mathrm{PCH}$ in children is rare [6-9].

\section{Case report}

A previously healthy, two-year-old boy was admitted to a regional hospital with a two-week history of upper respiratory tract infection. The day before admission, he had suffered from vomiting, dehydration, and decreased physical activity. His urine was dark-coloured. The next morning, he was very pale and mildly icteric. A physical examination did not reveal any organomegaly. Initial investigations showed severe anaemia (haemoglobin $6.5 \mathrm{~g} / \mathrm{dl}$ ), leukocytosis (WBC $29.050 / \mathrm{mm}^{3}$ ), normal platelet count (PLT 277.000/. $\mathrm{mm}^{3}$ ), and increased CRP (11.9 mg/dl; normal range $<1.0 \mathrm{mg} / \mathrm{dl}$ ). Other results were as follows: procalcitonin $44.4 \mathrm{ng} / \mathrm{ml}$, serum bilirubin $104 \mu \mathrm{mol} / \mathrm{l}$ with the indirect fraction of $95 \mu \mathrm{mol} / \mathrm{l}$, blood urea $148 \mathrm{mg} / \mathrm{dl}$, and serum creatinine $0.64 \mathrm{mg} / \mathrm{dl}$. Because of suspected haemolytic uraemic syndrome, the boy was transferred to the Department of Nephrology. On admission, at a physical examination, he was pale and dehydrated (about $8 \%$ ), blood pressure was $99 / 51 \mathrm{mmHg}$, heart rate was $138 \mathrm{bpm}$, saturation was $91 \% \mathrm{SiO}_{2}$, temperature was $37,8^{\circ} \mathrm{C}$, the urine was dark brown, and diuresis was $300 \mathrm{ml} /$ day. As an initial treatment, he immediately received boluses of normal saline and cefotaxime $(300 \mathrm{mg} / \mathrm{kg} /$ day in three doses, intravenously). The first blood samples were also examined for the ABO/Rh type and screened for antibodies. The blood type was AB RhD plus. The direct antiglobulin test (DAT) was positive for complement, with a C3c and C3d specificity, and IgG was negative. Warm haemolysins were detected. At the onset, laboratory tests were performed on: urine (proteinuria $400 \mathrm{mg} / \mathrm{dl}$, haemoglobinuria, and 1-3 erythrocytes per view field) and whole blood (haemoglobin $4.6 \mathrm{~g} / \mathrm{dl}, \mathrm{Ht} 11.5 \%$, RBC 1.37 million/ $/ \mathrm{mm}^{3}$,

Correspondence: Maria Daniel, Department of Paediatrics and Nephrology, Medical University of Warsaw, Żwirki i Wigury,

02-091 Warsaw, Poland, e-mail: maria.daniel@wum.edu.pl

Submitted: 30.12.2016; Accepted: 20.01.2017 
platelet count $241,000 / \mathrm{mm}^{3}$, WBC $20,800 / \mathrm{mm}^{3}$, with $59 \%$ of neutrophils, and reticulocyte count $19.8 \%$ ). The blood smear showed anisopoikilocytosis, RBC agglutination, and polychromasia. Other results were as follows: CRP $5.8 \mathrm{mg} / \mathrm{dl}$, procalcitonin $40 \mathrm{ng} / \mathrm{ml}$, GOT $148 \mathrm{U} / \mathrm{l}$, GPT $20 \mathrm{U} / \mathrm{l}$, bilirubin $95.7 \mu \mathrm{mol} / 1$, LDH $8525 \mathrm{U} / 1$, urea $137 \mathrm{mg} /$ $\mathrm{dl}$, creatinine $0.8 \mathrm{mg} / \mathrm{dl}$, GFR $43.9 \mathrm{ml} / \mathrm{min} / 1.73 \mathrm{~m}^{2}$ (grade 2 AKI according to the criteria of Acute Kindey Injury Network [6]), uric acid $6.5 \mathrm{mg} / \mathrm{dl}$, sodium $137 \mathrm{mEq} / \mathrm{l}$, potassium $5.1 \mathrm{mEq} / 1$, calcium $4.7 \mathrm{mEq} / \mathrm{l}$, phosphorus $3.6 \mathrm{mEq} / \mathrm{l}$, arterial blood gases were: $\mathrm{pH} 7.42, \mathrm{HCO}_{3} 21.8 \mathrm{mmol} / \mathrm{l}$, $\mathrm{BE}(-3.9) \mathrm{mmol} / \mathrm{l}, \mathrm{pO}_{2} 67 \mathrm{mmHg}, \mathrm{pCO}_{2} 66 \mathrm{mmHg}$, C3 $83 \mathrm{mg} / \mathrm{dl}, \mathrm{C} 48.0 \mathrm{mg} / \mathrm{dl}$, IgA, IgG, IgM were normal, and ANA, ANCA were negative. Abdominal ultrasonography showed normal-sized, hyperechogenic kidneys. The liver and spleen were of normal size. ECG and chest $\mathrm{X}$-ray were unremarkable.

These results suggested intravascular haemolysis with AKI. The boy was kept in a warm hospital room (room temperature $26^{\circ} \mathrm{C}$ ), with a cap on his head. He was hydrated intravenously and orally. All intravenous infusions were given through a heating apparatus. Due to the low $\mathrm{Hb}$ of $4.3 \mathrm{~g} / \mathrm{dl}$, he was transfused with packed red blood cells, and the post-transfusion $\mathrm{Hb}$ was $9.5 \mathrm{~g} / \mathrm{dl}$. Steroids started to be administered intravenously on the first day $(1.5 \mathrm{mg} / \mathrm{kg} / \mathrm{day})$. Because of two episodes of $\mathrm{Hb}$ decreasing to $7.0 \mathrm{~g} / \mathrm{dl}$, the boy was transfused with filtered red blood cells. Although warm haemolysins were detected, the clinical presentation resembled cold AIHA. Therefore, serologic tests were repeated. On the third day of hospitalisation, the DL test confirmed the presence of DL antibodies, and PCH was diagnosed. We continued the treatment with corticosteroids $(2 \mathrm{mg} / \mathrm{kg} /$ day for seven days), gradually decreasing the dose, Sandoglobulin P (a total dose of $18 \mathrm{~g}$ in three days) and cefotaxime for 10 days. After 10 days of treatment, laboratory tests showed: creatinine $0.3 \mathrm{mg} / \mathrm{dl}$ (GFR $105 \mathrm{ml} / \mathrm{min} / 1.73 \mathrm{~m}^{2}$ ), urea $24 \mathrm{mg} / \mathrm{dl}$, uric acid $4.0 \mathrm{mg} / \mathrm{dl}, \mathrm{Hb} 8.4 \mathrm{~g} / \mathrm{dl}$, reticulocytes $91 \%$, bilirubin $0.3 \mathrm{mg} / \mathrm{dl}$, GOT $32 \mathrm{U} / 1$, LDH $1163 \mathrm{U} / \mathrm{l}$, and normal urinalysis. Serological investigations for mycoplasma, EBV, CMV, HBV, HCV, and Parvovirus B19 were negative.

\section{Discussion}

$\mathrm{PCH}$ typically occurs in young children. The incidence ranges from $5.1 \%$ to $10 \%$, and the boy-to-girl ratio is $2.1: 1$ [1-4]. Almost all cases are acute and transient. Chronic $\mathrm{PCH}$ is very rare. Acute attacks are often severe, but the illness usually resolves spontaneously within a few days to several weeks after onset [1-5]. PCH should be suspected in any child with acute haemoglobinuria [1-4]. In our case, the diagnosis was based on the patient history, characteristic symptoms, a positive Coombs test, and a positive DL test. Children with PCH usually have a history of upper respiratory tract infection. As in our case, pallor, jaundice, and haemoglobinuria are the most common clinical findings. Hepatosplenomegaly is rare [1, 3, 4]. Typically, patients have anaemia with reticulocytosis, increased indirect bilirubin, and haemoglobinuria. Sometimes, reticulocytopaenia can occur in patients with ineffective marrow response to viral haemopoietic suppression [1]. In our patient, intravascular haemolysis was confirmed by anaemia, increased indirect bilirubin, $\mathrm{LDH}$, and haemoglobinuria. The C3c and C3d specificity found in DAT further suggested immune-mediated haemolysis. The diagnosis of $\mathrm{PCH}$ was delayed because in the first blood sample warm haemolysins were detected, but the clinical presentation was not typical for warm AIHA. At the onset, hepatosplenomegaly was not observed and reticulocytosis was in the normal range. Biphasic haemolysins were detected on the third day of hospitalisation. The reasons for the false negative DL test at the onset could be low antibody titre and inhibition of the antibody. The demonstration of the DL antibody is transient, and it may become undetectable by the time the patient's symptoms resolve $[1,2,10]$.

Our patient received supportive treatment: warming, hydration, blood transfusions, steroids, immunoglobulins, and antibiotics. The first-line PCH therapy is to avoid cold, in order to minimise $\mathrm{PCH}$-induced anaemia and recurrence of $\mathrm{PCH}[1-5,10]$. It is recommended that the patient's room is kept at $30^{\circ} \mathrm{C}$ until haemoglobinuria subsides [4, 5]. Our patient was kept in a warm room, with a cap on his head. All intravenous infusions were heated with a heating apparatus. Any patient with clinical signs and symptoms of anaemia with rapid haemolysis should be transfused with RBCs. Only filtered red blood cells are recommended, to prevent immunisation with HLA antigens [1-5]. Corticosteroids are often given, although it is difficult to evaluate their effectiveness $[1,3,5]$. Some studies suggest that steroids should be stopped immediately after diagnosing $\mathrm{PCH}$ [10]. Our patient started receiving steroids on the first day. The dose was gradually reduced and the treatment stopped after three weeks. Although at the onset warm haemolysins were detected, the patient was kept in a warm room, but he still had refractory episodes of anaemia, so we decided to add intravenous immunoglobulins to his treatment. Because of the long duration of the upper respiratory tract infection and the high indicators of inflammation at the onset, we decided to use antibiotic treatment, which was stopped only after normalisation of CRP and procalcitonin. Our patient showed a grade 2 AKI [6]. The mechanisms of AKI with intravascular haemolysis can include: renal tubular toxicity caused by the pigment resulting from the haemolysis, intratubular obstruction by pigmented cylinders, renal vasoconstriction due to inhibition of nitric oxide (a vasodilator), and concomitant depletion of blood volume in some patients. AKI can be a reaction to hypotension leading to acute tubular necrosis combined with severe complement activation and platelet aggregation. 
PCH often causes repeated microvascular thrombi, which are thought to mediate the widespread renal damage [10]. In our patient, during the supportive treatment of AKI, we observed a gradual improvement of GFR from 43.9 to $105 \mathrm{ml} / \mathrm{min} / 1.73 \mathrm{~m}^{2}$ during a 10-day period. Das et al. [8] described a two-year-old boy who had developed AKI secondary to $\mathrm{PCH}$. The boy required a peritoneal dialysis and plasma exchange. Gunawardena et al. [9] described a three-year-old girl with $\mathrm{PCH}$ and $\mathrm{AKI}$ who did not require renal replacement therapy.

\section{Conclusions}

In conclusion, a negative DL test should not exclude a $\mathrm{PCH}$ diagnosis in children if the clinical presentation is atypical for warm AIHA. Sometimes it is necessary to repeat the DL test. Some patients with mild AKI and PCH may be treated conservatively.

The authors declare no conflict of interest.

\section{References}

1. Petz LD, Garratty G (2004): Immune Hemolytic Anemias, Churchill Livingstone, Philadelphia.

2. Salido E, Cabańas V, Berenguer M, et al. (2014): Serological findings in a child with paroxysmal cold haemoglobinuria. Case Reports in Medicine 2014: 316010

3. Sobocińska-Mirska A, Adamowicz-Salach A, Michalewska B, et al. (2009): Paroxymal cold hemoglobinuria as underestimated cause of autoimmune hemolytic anemia in children. Pediatr Pol 84: 46-52.

4. Wynn RF, Stevens RF, Bolton-Maggs PH, et al. (1998): Paroxysmal cold hemoglobinuria of childhood: A review of the management and unusual presenting features of six cases. Clin Lab Haematol 20: 373-375.

5. Gertz MA (2007): Management of cold haemolytic syndrome. Br J Haematol 138: 422-429.

6. Mehta RI, Kellum JA, Shah SV, et al. (2007): Acute Kidney Injury Network: report of an initiative to improve outcomes in acute kidney injury. Crit Care 11: R31.

7. Hothi DK, Bass P, Morgan M, et al. (2007): Acute renal failure in a patient with paroxysmal cold hemoglobinuria. Pediatr Nephrol 22: 593-596.

8. Das K, Hughes D (2008): Paroxysmal cold haemoglobinuria leading to acute renal failure: A case report. Scott Med J 53: 60.

9. Gunawardena D, Velu M, Senaviratne SN (2012): Case report on a child with paroxysmal cold haemoglobinuria. Indian J Hematol Blood Transfus 28: 112-113.

10. Heddle NM (1989): Acute paroxysmal cold hemoglobinuria. Transfus Med Rev 3: 219-229. 